\title{
Achieving a holistic view of the life cycle performance of existing dwellings
}

\author{
A.A. Famuyibo ${ }^{a, *}$, A. Duffy ${ }^{a}$, P. Strachan ${ }^{b}$ \\ a School of Civil and Building Services Engineering and the Dublin Energy Lab, Dublin Institute of Technology, Dublin, Ireland \\ ${ }^{\mathrm{b}}$ Energy Systems Research Unit, University of Strathclyde, Glasgow, UK
}

\section{A R T I C L E I N F O}

\section{Article history:}

Received 5 March 2013

Received in revised form

8 August 2013

Accepted 10 August 2013

\section{Keywords:}

Holistic view

Housing stock

Archetypes

Life cycle energy

\begin{abstract}
A B S T R A C T
Models which fully evaluate the life cycle energy and greenhouse gas (GHG) emissions of national housing stocks are not reported in literature. Capturing a holistic view of energy and emissions of the residential sector is an important process that can lead to a more effective policy making. This paper presents a methodology which evaluates the life cycle energy and GHG emissions of retrofitting housing stocks considering all life cycle stages and incorporating, to the greatest extent possible, all upstream inputs.

To achieve this, we developed a hybrid model of the existing Irish housing stock, comprising a processbased approach supplemented by input - output LCA for installation of materials and fit-outs and maintenance of appliances. Life cycle analysis (LCA) is a commonly accepted technique for evaluating cradle-to-grave environmental impacts of a product. Using an assumed 50-year life span in all cases, representative archetypes were used to estimate the performance along retrofitting, operation, maintenance and disassembly phases of the three selected house retrofit scenarios: BaseCase (no intervention), Current Standards (retrofitting to meet current building regulations) and Passive House (retrofitting to meet Passive House Standards).

Results show that detached houses displayed the highest range of life cycle energy and exhibited the greatest absolute and percentage reductions compared to other house types, as life cycle energy ranges from $386-614 \mathrm{kWh} / \mathrm{m}^{2} \mathrm{yr}, 225-261 \mathrm{kWh} / \mathrm{m}^{2} \mathrm{yr}$ and $126-137 \mathrm{kWh} / \mathrm{m}^{2} \mathrm{yr}$ for all house scenarios, respectively. Using these results an assessment is provided for policy makers on a holistic view of the life cycle performance of existing dwellings.
\end{abstract}

(c) 2013 Elsevier Ltd. All rights reserved.

\section{Introduction}

The residential sector consumes approximately $30 \%$ of global primary energy [1], thus contributing significantly to greenhouse gas (GHG) emissions and global warming. In the EU, buildings are responsible for over $40 \%$ of energy use and a similar proportion of GHG emissions [2]. Although high, these figures may disguise the true global impact of building emissions since they account for operational activities (e.g. heating, cooling, lighting and small power) only. It is therefore important to fully account for and measure the energy use and emissions of a building throughout its life cycle which encompasses all the supply chain processes required for its production, operation and removal so as to assist policy makers and designers in understanding the true national, regional and global

\footnotetext{
* Corresponding author. Tel.: +353 14027937.

E-mail addresses: albert.famuyibo@dit.ie, sojarchi@yahoo.ie (A.A. Famuyibo).
}

impacts of buildings on the environment. This will lead to more effective decision making.

Life cycle analysis (LCA) is a commonly accepted approach for evaluating cradle-to-grave environmental impacts. For a building, life cycle stages include the extraction, refining, processing and production of raw materials and building materials, their use in construction, their disassembly and the operation and maintenance of the structure over its lifetime. Building-related environmental aspects and impacts of note include: Carbon dioxide $\left(\mathrm{CO}_{2}\right)$, Methane $\left(\mathrm{CH}_{4}\right)$, Nitrous oxide $\left(\mathrm{N}_{2} \mathrm{O}\right)$, Perfluorocarbons (PFCs), Hydro-fluorocarbons (HFCs) and Sulphur hexafluoride $\left(\mathrm{SF}_{6}\right)$ greenhouse gases as emissions to air, and Nitrogen oxides (NO [Nitric oxide] and $\mathrm{NO}_{2}$ [Nitrogen dioxide]) $\left(\mathrm{NO}_{x}\right)$, Sulphur dioxide $\left(\mathrm{SO}_{2}\right)$, Carbon monoxide (CO), Non-Metallic Volatile Organic Compounds (NMVOC) and particulate matter.

In many advanced economies, current building standards ensure that new buildings are highly operationally energy-efficient, resulting in low GHG emissions and environmental impacts relative 


\begin{tabular}{|c|c|}
\hline Symbols and units & \\
\hline$i$ & Unit archetype \\
\hline lcp & Life cycle phase. \\
\hline$E_{\text {process-lcp, } i}$ & $\begin{array}{l}\text { Process energy or emissions for each life cycle phase, } \\
\text { for archetype } i\left(\mathrm{kWh} \text { or } \mathrm{kgCO}_{2} \text {-eq) }\right.\end{array}$ \\
\hline$P E I_{m}$ & $\begin{array}{l}\text { Process energy or emissions intensity of material } \mathrm{m} \\
\text { for the life cycle phase being analysed }(\mathrm{kWh} / \mathrm{kg} \text { or } \\
\left.\mathrm{kgCO}_{2} \text {-eq } / \mathrm{kg}\right) \text {; and }\end{array}$ \\
\hline$Q_{m}$ & Quantity of material $m$ used in the life cycle phase $(\mathrm{kg})$. \\
\hline El-O-tot, i & $\begin{array}{l}\text { Total input-output energy/emissions prediction for the } \\
\text { refurbishment services of a unit archetype, } i \text { ( } k W h \text { and } \\
k g C O_{2} \text {-eq respectively). }\end{array}$ \\
\hline$E I_{j}$ & $\begin{array}{l}\text { Sub-sector embodied energy/emissions intensity of the } \\
\text { five Irish construction sub-sectors }(\mathrm{j}) \text { of Irish } \\
\text { construction }(\mathrm{kWh} / €)\end{array}$ \\
\hline$C_{j, i}$ & $\begin{array}{l}\text { I-O costs of refurbishment services for archetype } i \text {, } \\
\text { classified by Irish construction sub-sector } \mathrm{j}(€) \text {. }\end{array}$ \\
\hline$E_{\mathrm{I}-\mathrm{O}-\mathrm{Icp}, i}$ & $\begin{array}{l}\text { Input-output energy requirement/emissions of a } \\
\text { given life cycle phase of the unit archetype, } i\end{array}$ \\
\hline$C_{\mathrm{lcp}, i}$ & $\begin{array}{l}\text { Cost of refurbishment services for a given life cycle } \\
\text { phase of a unit archetype, } i \text {. }\end{array}$ \\
\hline$C_{\text {tot, } i}$ & Total cost of refurbishment services of archetype, $i$. \\
\hline$E_{\text {hybrid-tot-lcp, i }}$ & $\begin{array}{l}\text { Hybrid energy requirement/emissions of a given life } \\
\text { cycle phase of a unit archetype }\end{array}$ \\
\hline$E_{\text {hybrid-tot-lc, i }}$ & $\begin{array}{l}\text { Hybrid energy requirement/emissions of a unit } \\
\text { archetype, } i \text {. }\end{array}$ \\
\hline$\% E_{\text {hybrid-op-rs/bs, i }}$ & $\begin{array}{l}\text { Percentage of reduction in hybrid operational } \\
\text { energy/emissions of a unit archetype, } i \text { for a given } \\
\text { retrofit scenario relative to Basecase scenario. }\end{array}$ \\
\hline$E_{\text {hybrid-op-bs, i }}$ & $\begin{array}{l}\text { Hybrid operational energy/emissions requirement } \\
\text { of a unit archetype, } i \text { for the Basecase scenario. }\end{array}$ \\
\hline$E_{\text {hybrid-op-rs, i }}$ & $\begin{array}{l}\text { Hybrid operational energy/emissions requirement } \\
\text { of a unit archetype, } i \text { for a given retrofit scenario }\end{array}$ \\
\hline
\end{tabular}

to older buildings. The greatest challenge in these countries is to upgrade older, less efficient dwellings to higher energy efficiency standards. However, the system boundary in the energy analysis of these older dwellings is often narrowed or incorrectly expanded. The function of a building is to shelter and protect the occupants from inclement weather, resulting in their comfort. In a retrofit project the selected system boundary should be based on those processes that are related mainly to the function of the building. Concerns regarding aesthetic should be considered as being embedded in the function values of the building. The life cycle of a house retrofit project can then be categorised into four phases operation, retrofit, maintenance and disassembly. The system boundary of a house retrofit project should be limited to only those processes that can not be separated from the building. In a different perception as in the model of Erlandsson and Levin (2004) waste water treatment was assumed to be part of maintenance. However, the process should be better accounted for in the study of the metabolism of urban systems when considering sustainability of cities.

All of these factors make energy and emission evaluations of older dwellings challenging. While there is considerable information about operational phase energy reduction strategies for retrofitting housing stocks, there is far little knowledge on those attributable to retrofitting, maintenance and disassembly. A life cycle approach, however, should be taken to ensure that the level of refurbishment and system boundary chosen result in net emissions and energy savings over the projected lifespan of the upgrade. Moreover, the resulting marginal GHG abatement costs (MAC) should be economically efficient. However, a separate paper is proposed to discuss in detail the MAC of the retrofitted scenarios and the policy implications. Models which fully evaluate the life cycle energy and GHG emissions of national housing stocks are not reported in literature. Studies either omit certain life cycle phases or important upstream inputs; for example, none evaluated either the contribution of fuel supply chains to energy and emissions processes (such as exploration, extraction, refining, and transport) and services (such as the installation of materials and fit-outs and maintenance of heating appliances including servicing). Several studies have been carried out on the energy and environmental impacts attributable to different national housing stocks over various time periods. The BREHOMES model [3], the model developed by Johnston et al. (2005) [4] and the UK Domestic Carbon Model (UKDCM) 40\% house project [5] focus on the need to support the assessment of emissions mitigation policies in the UK residential sector. The work of Balaras et al. [6] looks at the options to reduce $\mathrm{CO}_{2}$ emissions of the Hellenic housing stock. In Ireland, Clinch et al. [7] assessed the Irish housing stock to predict energy and $\mathrm{CO}_{2}$ savings and Clinch and Healy [8] extended this work to estimate the cost benefit of building stock interventions required to reduce $\mathrm{CO}_{2}, \mathrm{SO}_{2}, \mathrm{NO}_{x}$ and $\mathrm{PM}_{10}$ emissions. However, these models only focus on the use phase of buildings. On the other hand, the work of Erlandsson and Levin (2004) [9] covers Swedish multidwelling houses built during the period 1940 to 1998 and beyond. However, the system boundary of the study focuses on the pre-use, retrofitting and maintenance (installation of urine system for use as fertilizer on a nearby farm) phases of dwellings. The actual regular maintenance of the buildings by replacing materials at the end of their service lives including maintenance of heating and ventilation appliances) was not included. Similarly, the disassembly phase of the building was omitted.

Therefore, the aim of this paper is to develop a methodology which evaluates the life cycle energy and GHG emissions impacts of housing stocks considering all life cycle stages and incorporating, to the greatest extent possible, all upstream inputs. This is then applied to the Irish housing stock by way of example. The method adopted involves the use of representative archetypes, each of which is refurbished to two different levels of energy efficiency: one which meets the energy and emissions requirements (Part L) of the current Irish building regulations [10]; and the other which meets the international Passive House standard [11-13]. The reason for assessing the latter is that the EU and Ireland have stipulated that all new dwellings should have near zero-emissions starting from 2020 [14]. The method for choosing thirteen archetypes which are representative of the Irish housing stock is not detailed here, but is reported in [15].

The remainder of this paper is presented as follows: Section 2 discusses the methodology and techniques used in the study. The results and discussion of the life cycle assessment for all house scenarios are presented in Section 3. Section 4 discusses the validation of the model used in the study. Conclusions are presented in Section 5.

\section{Methodology}

The research is divided into three parts. First, the life cycle impacts of each of the thirteen un-refurbished representative archetypes were evaluated to give the 'Base Case' energy and GHG emissions for each of the operational, retrofit, maintenance and disassembly phases. It should be noted that in stock aggregation, an archetype is a significant class of house, which can be extrapolated to the total energy consumption by the number houses for that archetype to represent the entire housing stock. In this study an archetype house represents a specific class of house (i.e. "As Is") in the existing Irish housing stock. The impacts of each archetype were assessed without intervention (except scheduled ordinary maintenance) to give a 'Basecase'.

Second, the detailed materials and labour required to achieve two levels of refurbishment were identified. The first level chosen met current building regulations and is referred to the 'Current 
Regulations' scenario. The second level was chosen to meet anticipated future (post 2013) regulations which are assumed to be a Passive House standard, and are referred to as the 'Passive House' scenario. These two levels involved identifying and modelling a range of interventions which achieved energy ratings equivalent to the Irish 2011 building regulations and Passive House standards, respectively. In each case, detailed bills of quantities were drawn up. In the third part of the research, the refurbished stock models were then reassessed to estimate their impacts on energy and emissions including the impacts of services. In all cases energy and primary energy-related $\mathrm{CO}_{2}$-equivalent emissions were calculated. Fig. 1 illustrates the overall research methodology used in this study. Similarly, Table 1 presents the summary of the archetypes and the refurbishment required to achieve both Current Regulations and Passive House scenarios.

\subsection{Developing representative archetypes}

The Base Case archetype model defines the characteristics of the 13 individual dwelling archetypes, which together represent $65 \%$ of dwellings in the existing Irish housing stock. The process of developing the archetypes [15] is summarised here. First, a multilinear regression analysis of a detailed housing database was performed to identify the most relevant variables associated with energy consumption. Second, using a statistical analysis of the distributions for each key variable, representative parameters were identified. Third, corresponding construction details were chosen using knowledge of housing construction details. Fourth, cluster analysis was then used to identify coincident groups of parameters and construction details. Fifth and finally, the 13 representative archetypes were developed using 9 representative construction details and 9 household variables of energy use.

\subsection{Hybrid LCA methodology}

A life cycle assessment (LCA) of each archetype was undertaken for the Base Case, Current Standards and Passive House options. The assessment was carried out in accordance with: ISO 14040 (2006) Environmental Management - life cycle assessment - Principles and framework [16]; and ISO 14044 (2006) - Environmental Management - life cycle assessment - Requirements and Guidelines [17]. A functional unit of ' $1 \mathrm{~m}^{2}$ total heated floor area' was chosen as the most adequate functional unit for the analysis because it relates to a unit area of living space and allows comparison with the results of other studies.

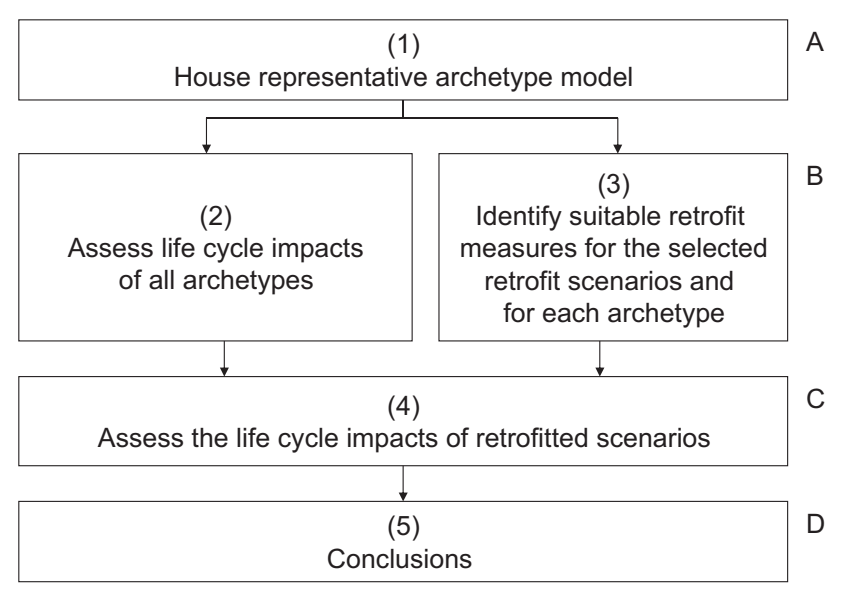

Fig. 1. Research methodology.
Two environmental impact categories were chosen: primary energy consumption and global warming potential. Both were chosen since they relate to key drivers of current national and international policy making in the built environment. Improving the energy efficiency of the Irish housing stock is a stated objective of the Irish government [18]; so too is the reduction of greenhouse gas emissions. Regarding the characterisation of environmental impact, global warming potential, an operational guide to the ISO Standards 2001 (CML, 2001) also referred to as the classical impact characterisation method of CML (Centre for Environmental Science, Leiden University) is used.

\subsubsection{Building system and system boundaries}

The building system represents the total system of processes required for the building [19], jointly with its related material and energy flows. In this study, the building system comprised four life cycle stages: operation, retrofitting, maintenance and disassembly. Each stage is made up of unit processes, each of which indicates one or numerous activities, such as the extraction or mining of raw materials, refinement, processing and manufacturing of products, on-site installation, use, retrofitting, maintenance, all associated transportation, detaching reusable materials, demolition of the building and removal of demolition waste. As earlier discussed, the scope of this work was limited by omitting all processes that are not related to the function of the building, and in particular those that can be separated from the building. The activities, processes and boundaries for each life cycle phase are described in the following paragraphs.

2.2.1.1. Operation phase. Operation phase of the building includes burdens (embodied primary energy and related emissions) from households' use of heat energy and electricity for space and water heating, lighting and appliances. It also includes burdens from transportation of purchased thermal heat (e.g. oil) from suppliers to the building site.

2.2.1.2. Retrofit phase. The retrofit phase in the building's life cycle encompasses all activities required in the application of energy savings components to the building. Material production for retrofit phase includes burdens from material extraction, refinement, processing and manufacture of materials, products and components including all associated transportation to site and back to recyclers those items that were replaced. It also includes all burdens associated with cost of labour required to remove existing energy savings components, as well as those needed in the installation of replacements.

2.2.1.3. Maintenance phase. The maintenance phase in the building's life cycle encompasses all activities required to produce all materials, products and components required to replace those that have expired (i.e. at the end of their service lives). Material production for the maintenance phase includes burdens from material extraction, refinement, processing and manufacture of materials, products and components including all associated transportation to site and back to recyclers the expired items. It also includes burdens from cost of labour for: regular servicing of heating appliances; installation of material substitutes, including all associated transportation.

2.2.1.4. Disassembly phase. The disassembly phase in the building's life cycle includes all activities required for detaching reusable materials, demolition of the actual building, loading and disposal of materials of disassembly. It includes burdens from: drilling, refinement and processing activities associated with fuels used for transportation. Other burdens associated with this phase include 
Table 1

Summary of archetypes and the refurbishment required to achieve both Current Regulations and Passive House standards.

\begin{tabular}{|c|c|c|c|c|c|}
\hline \multirow[b]{2}{*}{ Archetype reference $^{a}$} & \multicolumn{2}{|l|}{ Archetype description } & \multicolumn{3}{|l|}{ Scenario } \\
\hline & Variable & Material & BaseCase & Current regulations & Passive house \\
\hline $1-5,7-12$ & Partial fill cavity wall & Mineral wool (slab) & $0.5 \mathrm{~W} / \mathrm{m}^{2} \mathrm{~K}$ & $0.21 \mathrm{~W} / \mathrm{m}^{2} \mathrm{~K}$ & $0.12 \mathrm{~W} / \mathrm{m}^{2} \mathrm{~K}$ \\
\hline 6 & Full fill cavity wall & & $0.375 \mathrm{~W} / \mathrm{m}^{2} \mathrm{~K}$ & & \\
\hline 13 & Un-insulated cavity wall & & $1.625 \mathrm{~W} / \mathrm{m}^{2} \mathrm{~K}$ & & \\
\hline $4,7,9$ & Single-leaf wall & & $0.5 \mathrm{~W} / \mathrm{m}^{2} \mathrm{~K}$ & & \\
\hline $1,6-8,10-11$ & Ceiling insulation & Mineral wool (quilt) & $0.33 \mathrm{~W} / \mathrm{m}^{2} \mathrm{~K}$ & $0.16 \mathrm{~W} / \mathrm{m}^{2} \mathrm{~K}$ & $0.1 \mathrm{~W} / \mathrm{m}^{2} \mathrm{~K}$ \\
\hline $2-3$ & $\begin{array}{l}\text { (i.e. insulation } \\
\text { between joists) }\end{array}$ & & $0.46 \mathrm{~W} / \mathrm{m}^{2} \mathrm{~K}$ & & \\
\hline $4-5,9,12-13$ & Rafter insulation & & $0.33 \mathrm{~W} / \mathrm{m}^{2} \mathrm{~K}$ & & \\
\hline $2-3,13$ & & & $0.46 \mathrm{~W} / \mathrm{m}^{2} \mathrm{~K}$ & & \\
\hline $1,6-12$ & Insulated solid floor & Rigid foam (mm) & $0.5 \mathrm{~W} / \mathrm{m}^{2} \mathrm{~K}$ & $0.21 \mathrm{~W} / \mathrm{m}^{2} \mathrm{~K}$ & \\
\hline $2-5,13$ & $\begin{array}{l}\text { Un-insulated suspended } \\
\text { timber ground floor }\end{array}$ & & $0.58 \mathrm{~W} / \mathrm{m}^{2} \mathrm{~K}$ & & \\
\hline $7-8,10,13$ & Air change rate & Sealant & $0.94 \mathrm{ac} / \mathrm{h}$ & 0.35 & 0.25 \\
\hline $1,4,9,11-12$ & & & $0.87 \mathrm{ac} / \mathrm{h}$ & & \\
\hline 2,5 & & & $0.74 \mathrm{ac} / \mathrm{h}$ & & \\
\hline 6 & & & $0.67 \mathrm{ac} / \mathrm{h}$ & & \\
\hline $1-2,4-5,8-10$ & Windows & UPVC and glass & Double-glazed UPVC & Triple-glazing & Triple-glazing \\
\hline 6 & & & Low-e UPVC & (1 low-emissivity & (1 low-emissivity \\
\hline 3,13 & & & Single-glazed timber & coating, 2 gaps with & coating, 2 gaps \\
\hline $7,11-12$ & & & Double-glazed timber & $\begin{array}{l}\text { air to achieve a } \\
\text { U-value of } 1.6 . \text {.) }\end{array}$ & $\begin{array}{l}\text { with argon gas, } \\
\text { and integral } \\
\text { draught proofing } \\
\text { to achieve a U-value } \\
\text { of } 0.8 \mathrm{~W} / \mathrm{m}^{2} \mathrm{~K} \\
\text { (Gustavsson, } 2010 \text { ) }\end{array}$ \\
\hline $1-3,9,11-12$ & DHW cylinder & Factory-applied & $30^{\mathrm{b}}$ & $50 \mathrm{~mm}$ & $75 \mathrm{~mm}$ \\
\hline $5,7,10,13$ & & coating of & $35^{c}$ & & \\
\hline 4,6 & & polyurethane foam & $37^{c}$ & & \\
\hline 8 & & & $50^{\mathrm{b}}$ & & \\
\hline $1-2,4-6$ & $\begin{array}{l}\text { Heating system } \\
\text { and Controls/ } \\
\text { Low emissions } \\
\text { technologies }\end{array}$ & Not available & $\begin{array}{l}\text { Conventional oil boiler } \\
\text { (80\% efficiency) }\end{array}$ & $\begin{array}{l}\text { Condensing/boiler, } \\
\text { Solar hot water - } 4 \mathrm{~m}^{2} \\
\text { solar flat plate system }\end{array}$ & $\begin{array}{l}\text { Ground source } \\
\text { heat pump, } \\
\text { Solar hot water - } 4 \mathrm{~m}^{2} \\
\text { solar flat plate system, } \\
\text { Mechanical ventilation } \\
\text { plus heat recovery } \\
\text { (MVHR) and PV system }\end{array}$ \\
\hline 3 & & & $\begin{array}{l}\text { Conventional oil boiler } \\
\text { (70\% efficiency) }\end{array}$ & & \\
\hline $7-13$ & & & $\begin{array}{l}\text { Conventional gas boiler } \\
\text { ( } 80 \% \text { efficiency) }\end{array}$ & & $\begin{array}{l}\text { Air source heat pump, } \\
\text { Solar hot water - } 4 \mathrm{~m}^{2} \\
\text { solar flat plate system, } \\
\text { Mechanical ventilation } \\
\text { plus heat recovery } \\
\text { (MVHR) and PV system }\end{array}$ \\
\hline $1-13$ & & & $\begin{array}{l}\text { Standard controls } \\
\text { (e.g. single room } \\
\text { thermostat plus timer; } \\
\text { thermostatic } \\
\text { radiator valve control, } \\
\text { or Full time and } \\
\text { temperature zone control) }\end{array}$ & Advanced controls & Advanced controls \\
\hline $1-13$ & Lights & & Incandescent light bulbs & CFL lighting & CFL lighting \\
\hline
\end{tabular}

a Archetypes 1-6 are detached houses, archetypes 7-10 are semi-detached houses, and archetypes 11-13 are mid-terraced houses/apartments.

b DHW cylinder lagging jacket.

c Factory-applied coating of polyurethane foam (mm).

cost of labour for demolition and transportation of all materials of disassembly to a recycler, including all associated loading and offloading.

\subsubsection{Service lives of dwellings}

In order to evaluate the life cycle impacts of a building, its service life must be known. Assumptions regarding building service life duration varies across author and study for various reasons, ranging from differing economic life times of buildings in the country in question, to non-technical (e.g. rebound effect) and technical (e.g. material durability) considerations. Other factors that affect the service live of a building include climate, design, ease of maintenance, construction type, age, workmanship and relationship between embodied energy and life cycle energy). A commonly assumed service life of buildings is a 50-year period [20] although in some cases, service life is chosen as a 40-year period [19]. Using both non-technical and technical factors, Nemry et al., [21] evaluated the emissions reduction potential in EU buildings using residual service lives of 40 years for new dwellings and 20 years for older dwellings. Adalberth et al., [22] assumed a service life of 50 years for four multi-family buildings in Sweden because the economic life span of a building in Sweden is about 40-50 years. Scheuer et al. [23], assumed a 75 year service life for a mixed use building in Michigan.

On the basis that approximately 50\% of dwellings (including $32 \%$ representing those dwellings that were constructed prior to 1960) 


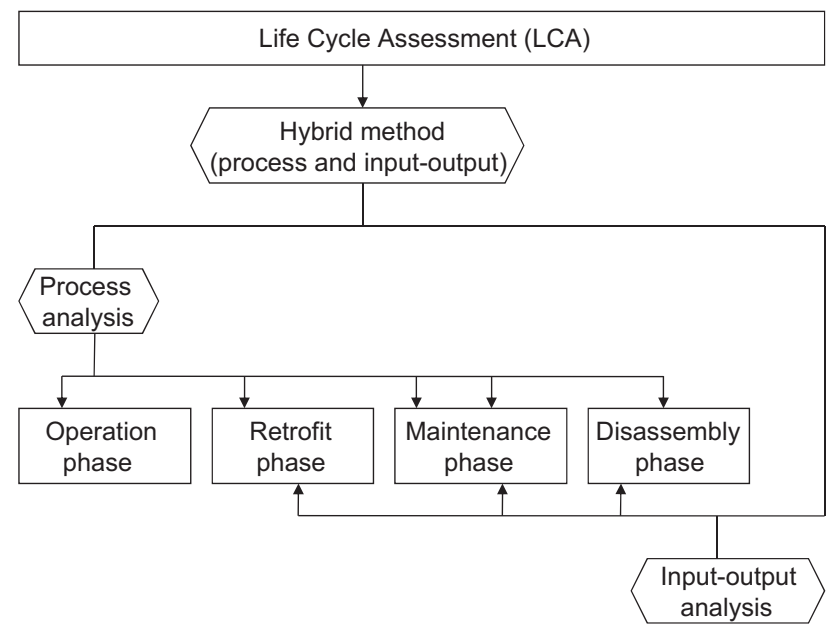

Fig. 2. Combination of methods and databases.

of the existing Irish housing stock are well over 45 years old [24] as at 2005 (baseline year of study), a common service life of 50 years for all the buildings within the population has been assumed for this study. The selected period will allow: 1) approximately 1 replacement for a majority of energy savings components (e.g. 20 or 25 years economic lifetime for a PV system ([25]), 20 years on average for a solar water heating system [26] and 20-40 years for windows [27]; and 2) No replacement for foundations and superstructures (i.e. $60+$ years) [27] and roof coverings (40-60 + years) [27]. It is assumed that such a selection will lead to striking a balance between embodied energy and operational energy. As more materials and components are replaced at the end of their service lives and of regular/scheduled maintenance embodied energy becomes increasing significant. At a point as the age of the building increases embodied energy may overtake and even dominate operational energy. At this point the building has outlived its economic lifetime. The cost of replacing roof coverings, foundations and even superstructures, including materials and components of regular/scheduled maintenance will exceed the economic and environmental implications of a corresponding new building. Limiting the lifetime of the building to 50 years as the economic lifetime so as to avoid the replacement of these fundamental components is therefore crucial.

\subsubsection{Sources of data}

The methodology described in this paper involves a combination of methods and databases. The Energy Performance Survey of Irish Housing (EPSIH) [28] provided the life cycle inventories of construction materials and quantities and energy types. The EPSIH involved a detailed physical, occupancy and energy survey of 150 Irish dwellings which were representative of the Irish housing stock. It was undertaken in 2005.

The Housing Energy Model (HEM) energy software was selected to evaluate the annual operation energy for the different retrofit options because of its regional representativeness, together with the inclusion of the relevant demand-related inputs. The annual operational energy calculation was based on the parameters of the characteristics (including fabric determinants, heating system determinants and context determinants) of the archetypes. HEM has been designed for use at local and national levels by different categories of stakeholders, such as policy makers involved in building regulations and building stock owners in the appraisal of energy efficiency measures [29]. GaBi 4.4 was selected to evaluate the operational energy-related environmental impacts of the representative archetype dwellings, given the operational energy requirements obtained from HEM, and in particular as GaBi 4.4 software can not be used to evaluate house annual energy use based on those characteristics earlier mentioned.

In calculating hybrid energy and emissions, process analysis was used for material quantities to which process emissions intensities can be applied. Overall, process analysis data covers the physical flows of all processes that are related to the production, consumption, retrofitting, maintenance and disassembly phases of the house in question. Background datasets are provided within the GaBi 4.4 software tool developed by the PE International of Germany [30]. Background datasets refer to 'Professional'- standard database used in industry, including ELCD database, as well as data from APME/PlasticsEurope, and 'Extensions databases' (e.g. steel, aluminium, electronics, renewable raw materials, manufacturing processes, intermediate [organic and inorganic], textile finishings, construction, etc. GaBi 4.4 contains construction database or datasets which encompass the mainly relevant construction materials, including additional specialised materials used in the construction of buildings. The construction database is categorised into mineral products (including concrete, concrete products, bricks and natural stones); ready-to-use building materials (including different types of windows and frame types). The technologies of the transportation datasets are representative Europe wide. These technologies can be adapted in different countries to suit country specific background datasets (e.g. transportation distance and weight of materials to be transported) [30]. Other sources of process data include the energy and emissions intensities of Irish construction sub-sectors from a previous Irish study by [31]. Fig. 2 illustrates the combination of methods and databases used in the study.

Since the materials and processes within the building systems are similar for all archetypes, a generic parameterised model was developed in GaBi 4.4 in order to adapt the model to each of the representative archetypes. The generic parameterised building model allows the simplification of the handling of the extended quantity of data and maintains consistency and transparency of results during the assessment of each archetype [21]. The developed parameterised model can be adjusted with parameter variations to allow its adaptation without the need to developing a whole new model for each of the archetypes [30].

Given the uncertainty regarding future energy mixes, it is assumed that the energy supply system will be constant during the entire lifetime of the building when calculating emissions. Irish current electricity grid mix has been used to evaluate the environmental impact induced by electricity production for all buildings. Similarly, environmental impacts from heat production were calculated using Irish fuel parameters for natural gas and oil using GaBi energy and emissions conversion factors.

Input output ( $\mathrm{I}-\mathrm{O})$ analysis [32] was used for assessing energy and emissions where no materials quantities and/or process emissions intensities could be obtained. Monetary flow data was obtained from a combination of sources. Retrofit upgrades were designed based on the physical parameters reported in the EPSIH database as well as the requirements of existing building regulations and the Passive House standards. Data on the costs of materials, products, labour costs, profits and overheads were obtained from Spon's Irish construction price book [33] and Spon's Mechanical and Electrical Price Book [34],. These were then adjusted to a 2005 base year. The price books also provide additional information on plant hire and other services. I-O data was obtained from a previous Irish study, Acquaye [31] and included construction energy $(\mathrm{kWh} / €)$ and emissions intensities $\left(\mathrm{kgCO}_{2}\right.$-eq/€) broken down by subsector: 'Ground Works', 'Structural Work', 'Services', 'Finishes' and 'Plant Operation'. 


\subsubsection{Life cycle inventories}

Using the various sources of data discussed in the previous section, life cycle inventories (LCIs) for all retrofitting materials, energy sources and costs of services (installation of materials and fit-outs) were generated. The LCI comprises an inventory of all inputs and outputs over the life cycle of the building. The building service live and the life expectancy of the products and materials were also used in this process. The rate of replacement results in the number of replacements of products (e.g. replacing a PV system every 20 or 25 years) and number of upgrade actions (e.g. internal and external redecorations every 7 and 10 years, respectively) for each construction detail over the service life of the building.

For the disassembly phase, the study assumes there is a recycler near the building at approximately $50 \mathrm{~km}$. The transport dataset from GaBi 4.4 already accounts for the transportation of fuels from the point of extraction or mining to the manufacturing centre of the required finished products. However, transportation burdens from the mainstream and downstream sectors are also based on the transportation dataset from $\mathrm{GaBi} 4.4$ and are modelled based on an assumed distance of $50 \mathrm{~km}$ from suppliers to the building site, and of waste from building site to recyclers.

Inventories of some processes and features were excluded from the house system boundary either due to their overall insignificance or because they fell outside the study boundary. It would be recalled that the system boundary of the study is limited to only those processes that can not be separated from the building. This study was therefore limited to building elements, heating systems, and electrical systems.

\subsubsection{Calculation of process-based hybrid energy/emissions}

The calculation of hybrid energy and emissions can be split into two sections: an estimation of process analysis energy and emissions; and $\mathrm{I}-\mathrm{O}$ analysis energy and emissions. The hybrid energy and emissions are obtained as the sum of the process and I-O LCA figures. Fig. 3 illustrates how the input-output and process techniques were combined for this project (the bolded figures represent the three steps followed in the calculation). The process energy and emissions across operational, maintenance, retrofit and disassembly phases were calculated using $\mathrm{GaBi}$ and the bill of quantities prepared for the refurbishment works. The residual values of materials and services not used in the process analysis (omitted either because they could not be measured by mass or because no relevant emissions intensities were available) were classified into their relevant Irish construction sub-sector and multiplied by the corresponding energy and emissions intensities. These were summed and added to the process values to give the total hybrid LCA emissions for the Base Case, Current Regulations and Passive House scenarios.

The process energy and emissions for each life cycle phase is given by:

$E_{\text {process-lcp }, i}=\sum_{m} P E I_{m} \times Q_{m}$

Where: $\mathrm{lcp}=$ life cycle phase

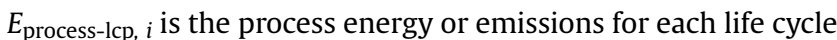
phase (lcp) for archetype, $i\left(\mathrm{kWh}\right.$ or $\mathrm{kgCO}_{2}$-eq);

$\mathrm{PEI}_{m}$ is the process energy or emissions intensity of material $m$ for the life cycle phase being analysed $\left(\mathrm{kWh} / \mathrm{kg}\right.$ or $\mathrm{kgCO}_{2}$-eq/ $\mathrm{kg}$ ); and

$Q_{m}$ is the quantity of material $m$ used in the life cycle phase $(\mathrm{kg})$.

The input-output energy requirement/emissions of a given life cycle phase for the refurbishment services of a unit archetype, $i$ was calculated by first calculating the total input-output energy requirement/emissions of a unit archetype, $i$. The total input-output energy/emissions prediction for the refurbishment services of a unit archetype, $i$ can be represented by equation (2).

$E_{\mathrm{I}-\mathrm{O}-\mathrm{tot}, i}=\sum_{j=1}^{5}\left(E I_{j} * C_{j, i}\right)$

$\mathrm{E}_{\text {I-O-tot, } \mathrm{i}}=$ Total input-output energy/emissions prediction for the refurbishment services of a unit archetype, $i$.

$\mathrm{EI}_{j}=$ sub-sector embodied energy/emissions intensity of the five Irish construction sub-sectors $(j)$ of Irish construction $(\mathrm{kWh} / €)$.

$C_{j, i}=\mathrm{I}-\mathrm{O}$ costs of refurbishment services for archetype $i$, classified by Irish construction sub-sector $j(€)$.

Then the input-output energy requirement/emissions of a given life cycle phase of the unit archetype, $i$ can be represented by equation (3):

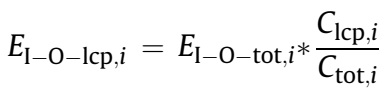

Characteristics of the developed archetypes

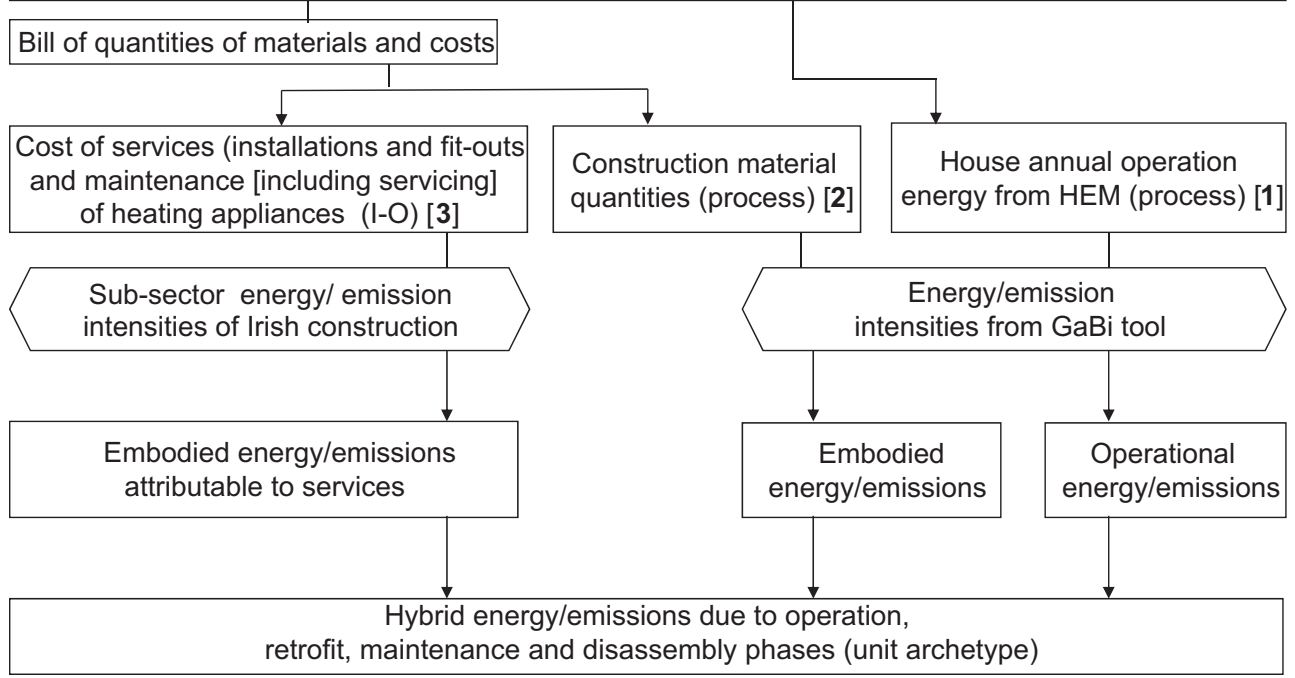

Fig. 3. Combination of input-output and process techniques used in evaluating the hybrid LCA energy/emissions. 
$C_{\mathrm{lcp}, i}=$ cost of refurbishment services for a given life cycle phase of a unit archetype, $i$.

$C_{\mathrm{tot}, i}=$ total cost of refurbishment services of archetype, $i$.

$E_{\mathrm{I}-\mathrm{o}-\mathrm{lcp},} i=$ input-output energy requirement/emissions of a given life cycle phase of the unit archetype, $i$.

The hybrid result is some combinations of the process and $\mathrm{I}-\mathrm{O}$ results. Thus, the hybrid energy requirement/emissions of a given life cycle phase of a unit archetype, $i$ is the sum of its process and input-output energy/emissions.

$E_{\text {hybrid-tot-lcp }, i}=E_{\text {process-lcp }, i}+E_{\mathrm{I}-\mathrm{O}-\mathrm{lcp}, i}$

Where, $E_{\text {hybrid-tot-lcp, i }}=$ hybrid energy requirement/emissions of a given life cycle phase of a unit archetype, $i$.

Similarly, the hybrid life cycle energy requirement/emissions of a unit archetype, $i$ is the sum of the process energy/emissions across use, retrofit, maintenance and disassembly phases, and the corresponding input-output energy requirement/emissions.

$E_{\text {hybrid-tot-lc }, i}=\sum_{\mathrm{lcp}=1}^{4} E_{\text {process-lcp }, i}+\sum_{\mathrm{lcp}=1}^{3} E_{\mathrm{I}-\mathrm{O}-\mathrm{lcp}, i}$

$E_{\text {hybrid-tot-lc, } i}=$ hybrid energy requirement/emissions of a unit archetype, $i$.

$E_{\text {process-lcp, } i}=$ process energy/emissions across operation, retrofit, maintenance and disassembly phases.

$E_{\mathrm{I}-\mathrm{o}-\mathrm{lcp}, i}=$ input-output energy requirement/emissions across retrofit, maintenance and disassembly phases.

The scale of reduction in operational energy consumption of all archetypes was also calculated for all retrofit scenarios. This was considered necessary since the phase is the most important life cycle phase. This was calculated as a percentage for the respective unit archetype, $i$ across all retrofit scenarios relative to BaseCase energy/emission. The percentage of reduction in operational energy/emission of a unit archetype, $i$ for a given retrofit scenario is represented by:

$\% E_{\text {hybrid-op-rs } / \mathrm{bs}, i}=\frac{\left(E_{\text {hybrid-op-bs }, i}-E_{\text {hybrid-op-rs }, i}\right)}{\mathrm{E}_{\text {hybrid-op-bs }, i}} * 100$

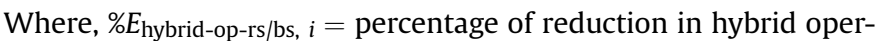
ational energy/emissions of a unit archetype, $i$ for a given retrofit scenario relative to Basecase scenario.

$E_{\text {hybrid-op-bs, } i=\text { hybrid operational energy/emissions require- }}$ ment of a unit archetype, $i$ for the Basecase scenario.

$E_{\text {hybrid-op-rs, } i=\text { hybrid operational energy/emissions require- }}$ ment of a unit archetype, $i$ for a given retrofit scenario

\subsubsection{Energy/emissions of retrofitted scenarios}

For each of the 13 archetypes indicated in Table 1 and the refurbishment required, the generic parameterised model initially developed in GaBi 4.4 tool was altered based on the corresponding life cycle input data to evaluate the new energy and emissions. The new energy and emissions of the retrofitted scenarios were then compared to the BaseCase scenario.

\section{Results and discussion}

The following subsections present the results and discussion at archetype and life cycle phase levels.

\subsection{Life cycle energy at archetype level}

\subsubsection{Base Case}

Fig. 4 shows the life cycle primary energy use results of all archetypes for all scenarios according to archetype dwelling type. Overall, the life cycle primary energy of all archetypes for the Base Case scenario ranges between 259 and $614 \mathrm{kWh} / \mathrm{m}^{2}$ yr. When considered according to dwelling type the range of primary energy requirements are: $386-614 \mathrm{kWh} / \mathrm{m}^{2}$ yr for detached house archetypes; $272 \mathrm{kWh} / \mathrm{m}^{2} \mathrm{yr}$ for semi-detached house/end-terraced house archetypes; and $259-501 \mathrm{kWh} / \mathrm{m}^{2} \mathrm{yr}$ for mid-terraced house/apartment archetypes. The energy use in detached house archetypes reflects their higher wall, roof, floor and window areas and the use of oil-fired boilers when compared to other archetypes. It should be noted that the high value for archetype 3 relative to other detached houses is due to its low level of envelope insulation (single-glazed wooden windows and little roof insulation). Semidetached house archetypes exhibit little variation due of their similar U-values and geometries. Among the mid-terraced houses/ apartments, archetype 13 is the greatest energy user due to its relatively poor envelope insulation (un-insulated cavity wall, single-glazed wooden windows, un-insulated suspended timber ground floor and a low level of roof insulation). The life cycle primary energy consumption for archetype 3 was so odd because of its poor envelope insulation (including draught-proofed single-glazed windows), low heating system efficiency (including an oil boiler) and the incorporation of DHW cylinder lagging jacket. Similarly, the performance of archetype 13 is equally odd due to its poor envelope insulation, but much better than that of archetype 3 because of its higher heating system efficiency and the incorporation of DHW cylinder foam.

\subsubsection{Current regulation}

All retrofit scenarios yield significant life cycle primary energy improvements compared to the Base Case scenario. Overall, the Current Regulations life cycle primary energy consumption ranges between 151 and $261 \mathrm{kWh} / \mathrm{m}^{2}$ yr for all archetypes. Life cycle primary energy use decreases by at least $41 \%$ for the Current Regulations option for all archetypes when compared to the Base Case scenario. For this option, detached house archetypes display the highest life cycle primary energy use, ranging from 225 to $261 \mathrm{kWh} / \mathrm{m}^{2} \mathrm{yr}$. Corresponding values for mid-terraced houses/ apartments range from 151 to $201 \mathrm{kWh} / \mathrm{m}^{2} \mathrm{yr}$ while semi-detached houses/end-terraced houses record the lowest life cycle primary energy use of approximately $160 \mathrm{kWh} / \mathrm{m}^{2} \mathrm{yr}$.

It is worth noting that the energy reduction for archetype 3 compared with archetype 6 was so dramatic because of its greater potential for energy reduction (see section on Basecase scenario). Moreover, the stunning nature of the life cycle energy reduction between these two archetypes is also related to the difference in their number of storeys while having the same floor area archetype 3 is a bungalow whilst archetype 6 is a two storey house. The higher life cycle energy reduction by archetype 3 therefore, reflects the greater area of exposed floor and roof, from which heat loss can be minimised. The above theory is also true for the dramatic energy reductions recorded for archetypes 11 or 12 vs. archetype 13 . Archetypes 11 and 12 are both 2-storey buildings with similar U-values and characteristics, but with different roof construction details (e.g. ceiling/rafter insulation) and much better envelope insulation compared to archetype 13 . Archetype 13 is 3storey building.

\subsubsection{Passive house}

For the Passive House retrofit scenario, detached houses show the highest range of life cycle primary energy use, ranging from 126 


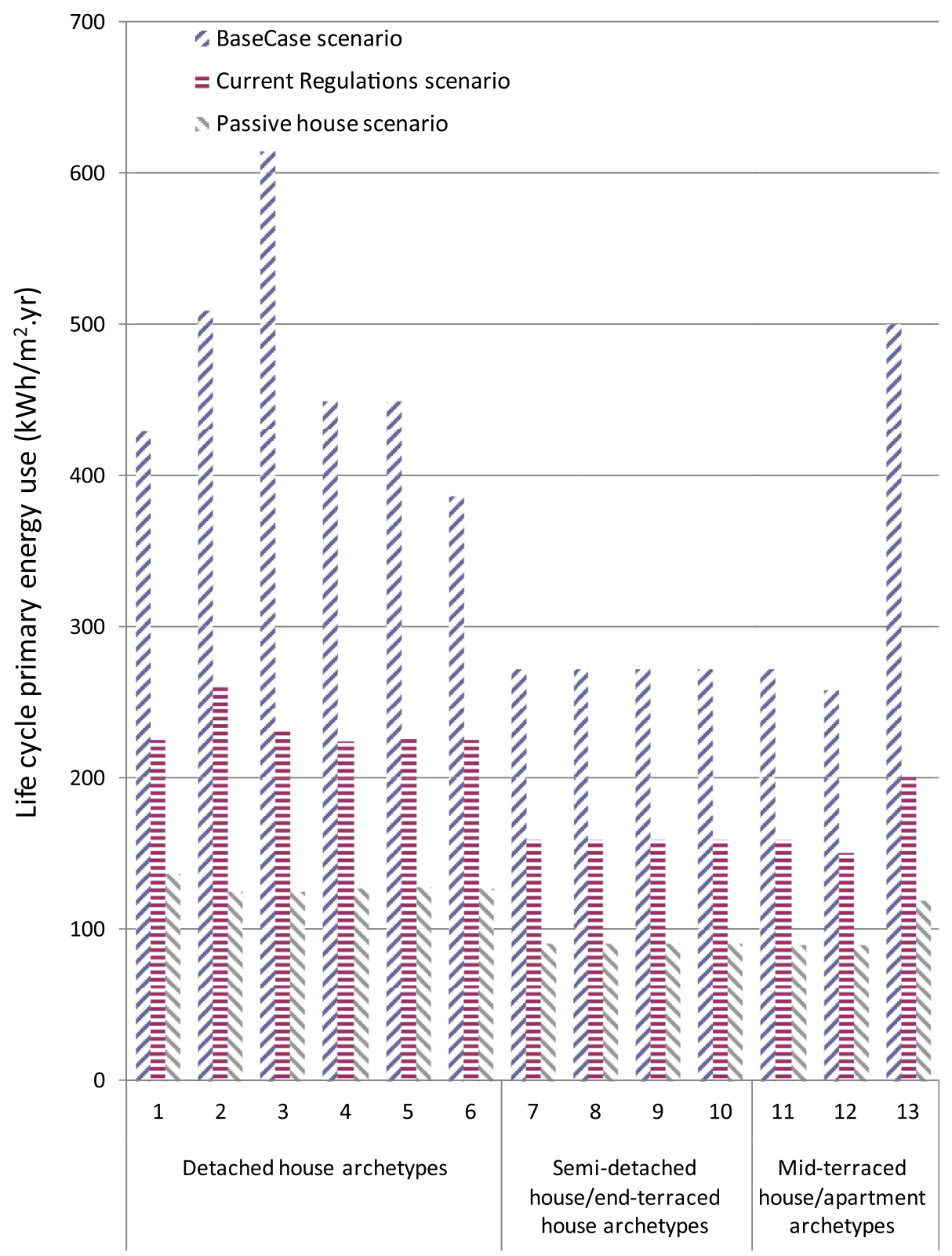

Fig. 4. Life cycle primary energy use $\left(\mathrm{kWh} / \mathrm{m}^{2} \mathrm{yr}\right)$ of all archetypes for all scenarios.

to $137 \mathrm{kWh} / \mathrm{m}^{2} \mathrm{yr}$. The corresponding values for mid-terraced houses/apartments and semi-detached houses/end-terraced houses are $90-120 \mathrm{kWh} / \mathrm{m}^{2} \mathrm{yr}$ and $90 \mathrm{kWh} / \mathrm{m}^{2} \mathrm{yr}$, respectively. This represents a decrease of at least $65 \%$ when compared to the Base Case scenario.

\subsubsection{Current regulation versus passive house}

A comparison between Current Regulations and Passive House scenarios indicates that life cycle primary energy reductions range between 61 and $135 \mathrm{kWh} / \mathrm{m}^{2}$ yr for all archetypes. Detached house archetypes display the highest life cycle primary energy use, ranging from 88 to $135 \mathrm{kWh} / \mathrm{m}^{2}$ yr. Corresponding values for semidetached houses/end-terraced houses range from 61 to $82 \mathrm{kWh} /$ $\mathrm{m}^{2} \mathrm{yr}$ while mid-terraced houses/apartments houses record the lowest life cycle primary energy use reductions of approximately $69 \mathrm{kWh} / \mathrm{m}^{2} \mathrm{yr}$. The low range of energy reductions for this comparison can be explained as the building becomes increasingly more energy efficient.

\subsubsection{Emissions}

Fig. 5 indicates global warming potential $\left(\mathrm{kgCO}_{2}-\mathrm{eq} / \mathrm{m}^{2} . \mathrm{yr}\right)$ for all archetypes across life cycle phases for the different house scenarios. The linear correlation between resource uses and GHG emissions is emphasized as this table directly reflects that of the primary energy shown in Fig. 5.

\subsection{Primary energy use across life cycle phases}

Table 2 shows the proportion of primary energy used for each life cycle phase for each archetype and scenario. It can be seen that the operational phase dominates primary energy use; although not shown here, this result is repeated for emissions. This proportion, however, decreases as the standard of retrofit increases. For the Base Case scenario almost all life cycle energy use is accounted for by the operational phase. This reflects the high heating energy demand and electricity use during the operational phase, especially as the existing Irish housing stock has been described as one of the 


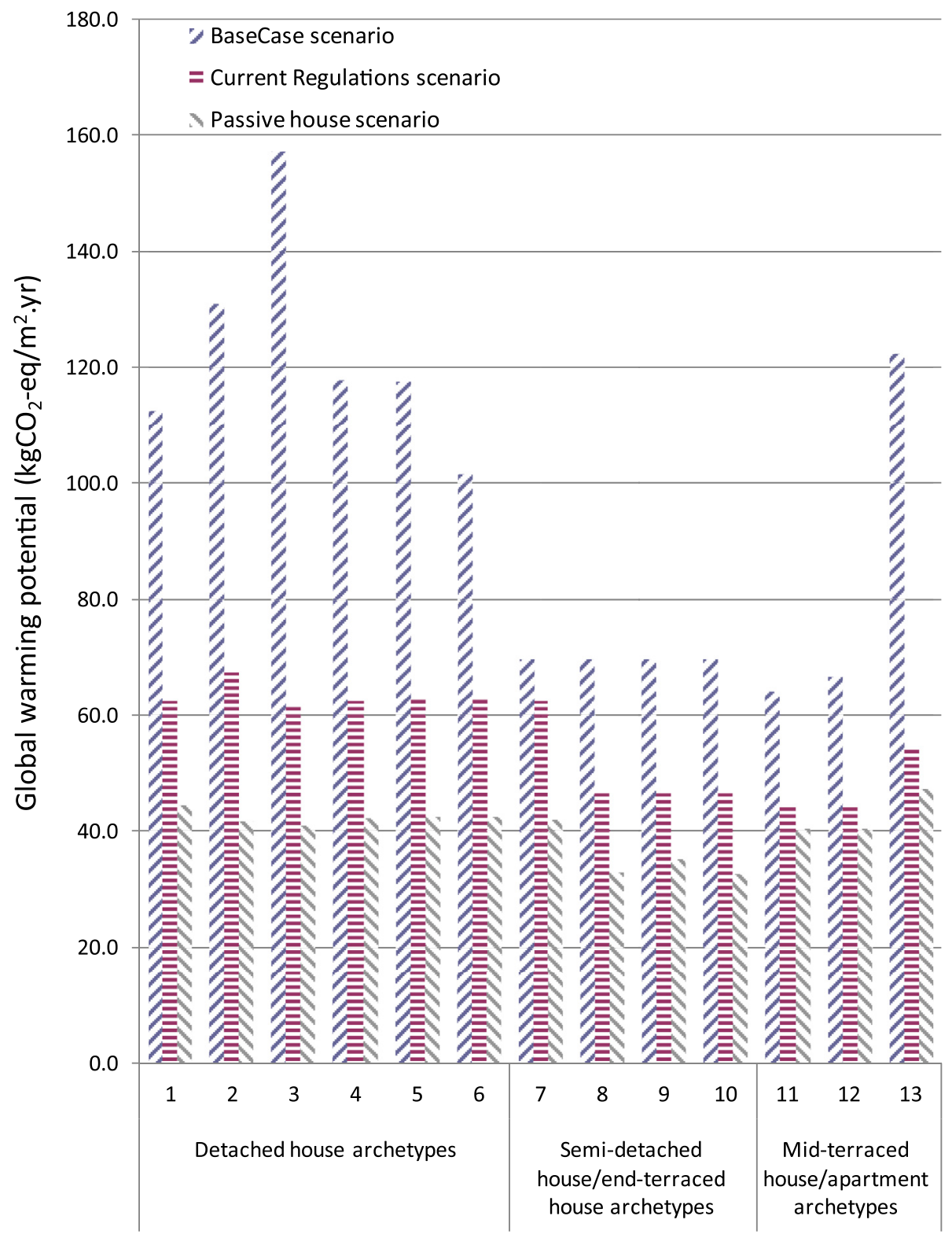

Fig. 5. Global warming potential $\left(\mathrm{kgCO}_{2}-\mathrm{eq} / \mathrm{m}^{2} . \mathrm{yr}\right)$ of all archetypes for all scenarios.

least energy efficient in Northern Europe [35]. The high heating energy demand results in proportionately low contributions from the maintenance and disassembly phases. When upgraded to meet current building regulations, the proportion of operational energy decreases approximately 93-95\%; the proportion falls further to 85-90\% for dwellings meeting the Passive House standard. These proportions are similar for all archetypes although they are slightly lower for semi-detached houses.

Table 3 shows the energy use for each archetype and retrofit scenario for the operational phase. The results of the operational energy use in Table 3 were calculated using equations (1)-(5). Similarly, the percentage of reduction in operational energy use was calculated using equation (6) (see Section 2.2.5). Overall the operational primary energy decreases by between $44 \%$ and $82 \%$ for the Current Regulations and Passive House standard scenarios respectively compared to the Base Case scenario. It can be seen that operational energy use decreases for all archetypes as the standard of retrofit increases. Operational energy use decreases by $44-64 \%$ for the Current Standards scenario, the largest reductions being evident for detached dwellings with poor insulation standards. Archetype 13 also exhibits high reductions due to the low Base Case construction standards for this dwelling type. Energy use reductions range from 69 to $82 \%$ for the Passive House option; again the highest reductions are seen for detached houses for the same reasons.

Overall, the above reductions in operational energy and emissions resulted from the incorporation of good thermal insulation of the envelope, substitution of the existing oil-fired boiler with condensing instantaneous gas-fired water heating boiler (Current Regulations scenario), avoidance of fossil fuel-fired heating systems (Passive House scenario), reduced thermal bridging, improved air tightness; and low-energy glazing.

The aim of this paper is to develop a methodology which evaluates the life cycle energy and GHG emissions impacts of retrofitting housing stocks considering all life cycle stages and incorporating, to the greatest extent possible, all upstream inputs. This aim has been 


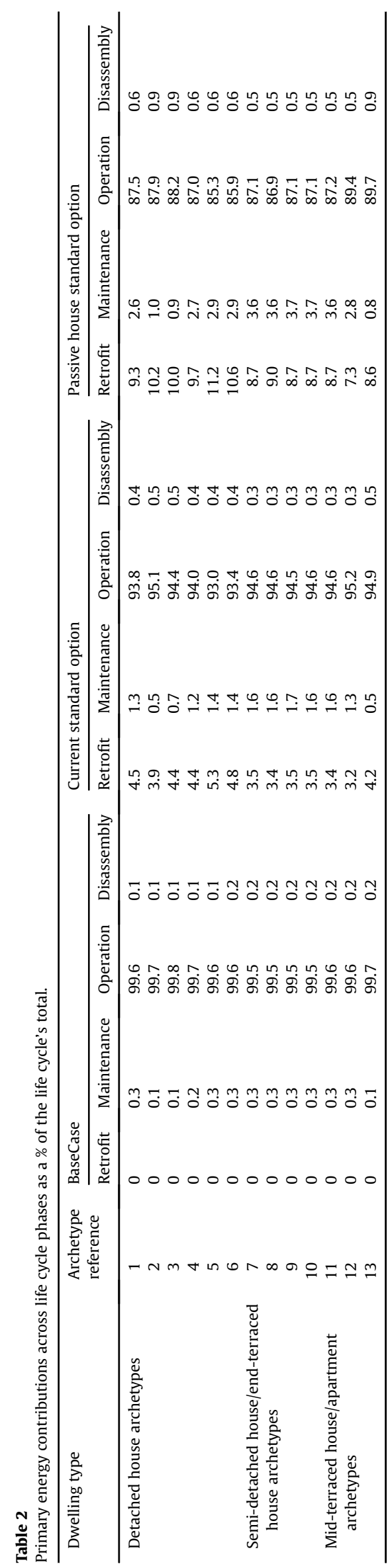

realized within the hybrid LCA that was performed. Studies earlier mentioned in the literature review section were mainly based on a bottom-up process analysis technique, while that of Clinch et al. (2001), in addition inferred parameters from national statistics in cases where household-level data were lacking. Moreover, all these studies used a weighted average dwelling approach and incomplete system boundaries to perform energy analyses.

However, this paper proposes a new hybrid LCA model for retrofitting residential building stocks. The model combines both process analysis and input-output analysis and comprises: an archetype model that was previously developed based on modal values of representative parameters to achieve a more accurate representation of the whole building stock, an energy modelling tool, and an LCA software tool. The expanded boundary system used in this paper considers the proportion of energy/emissions associated with the installation of energy savings components and the ordinary scheduled maintenance (including servicing of heating appliances) over the service life of the building. Results in Table 2 also show that focussing solely on the reduction of energy consumption during the operation of a building ignores the fact that as the building becomes more energy efficient the proportion of embodied energy attributable to retrofitting, maintenance and disassembly becomes increasingly significant. Such information can have an impact on the residential sector's overall performance. The models of Clinch et al. (2001), Erlandsson and Levin (2004) and other cited studies in Section one ignore this aspect.

\section{Validation}

The house annual operational energy was generated based on the characteristics of the house archetypes. A validation performed by a previous study [36], shows that using the well validated HEM energy model and GaBi 4 LCA model generated energy consumption of the existing Irish housing stock across life cycle phases. The prediction from the combination of these models shows that the weighted mean annual operational primary energy requirement per $\mathrm{m}^{2}$ was generally consistent with both national statistics and literature. It should be noted that this study is a piece of the cited previous study.

\section{Conclusions}

In conclusion, the hybrid LCA model as presented in this paper was shown to be an adaptable tool for assessing the life cycle energy and GHG emissions impacts of retrofitting housing stocks. The model considered all life cycle stages and incorporating, to the greatest extent possible, all upstream inputs so as to assist policy makers and designers in understanding the true national, regional, and global impact of buildings on the environment. It should be noted that the incorporation of all upstream activities in this study is crucial as electricity and heating energy requirements of Ireland like many advanced economies are mainly based on imported fossil fuels. The methodology can be applied in other countries using the respective national data and subsector energy/emissions intensities for services. The use of more holistic approaches and increased system boundaries to include all relevant processes and activities for the evaluation of a holistic view of energy and emissions attributable to retrofitting housing stocks is therefore crucial. The results of the analysis show that life cycle energy for the Base Case archetypes were highest, ranging from 259 to $614 \mathrm{kWh} / \mathrm{m}^{2}$ yr with successively lower emissions for the Current Standards and Passive House retrofit options which were $151-261 \mathrm{kWh} / \mathrm{m}^{2} \mathrm{yr}$ and $90-137 \mathrm{kWh} / \mathrm{m}^{2} \mathrm{yr}$ respectively. Overall the operational primary energy decreased by between $44 \%$ and $82 \%$ for the Current Regulations and Passive 
Table 3

Operational primary energy of all archetypes for retrofitted scenarios compared to the BaseCase scenario.

\begin{tabular}{|c|c|c|c|c|c|c|}
\hline Dwelling type & $\begin{array}{l}\text { Archetype } \\
\text { reference }\end{array}$ & $\begin{array}{l}\text { BaseCase } \\
\text { scenario } \\
\mathrm{kWh} / \mathrm{m}^{2} \cdot \mathrm{yr}\end{array}$ & $\begin{array}{l}\text { Current } \\
\text { regulations } \\
\text { scenario } \\
\mathrm{kWh} / \mathrm{m}^{2} \cdot \mathrm{yr}\end{array}$ & $\begin{array}{l}\% \text { Reduction } \\
\text { relative to } \\
\text { BaseCase }\end{array}$ & $\begin{array}{l}\text { Passive } \\
\text { house } \\
\text { scenario } \\
\mathrm{kWh} / \mathrm{m}^{2} . \mathrm{yr}\end{array}$ & $\begin{array}{l}\% \text { Reduction } \\
\text { relative to } \\
\text { BaseCase }\end{array}$ \\
\hline \multirow[t]{6}{*}{ Detached house archetypes } & 1 & 428 & 211 & 51 & 120 & 72 \\
\hline & 2 & 509 & 248 & 51 & 111 & 78 \\
\hline & 3 & 613 & 220 & 64 & 111 & 82 \\
\hline & 4 & 449 & 211 & 53 & 111 & 75 \\
\hline & 5 & 448 & 211 & 53 & 110 & 75 \\
\hline & 6 & 384 & 211 & 45 & 110 & 71 \\
\hline \multirow{4}{*}{$\begin{array}{l}\text { Semi-detached } \\
\text { house/end-terraced } \\
\text { house archetypes }\end{array}$} & 7 & 271 & 151 & 44 & 79 & 71 \\
\hline & 8 & 271 & 151 & 44 & 79 & 71 \\
\hline & 9 & 271 & 151 & 44 & 79 & 71 \\
\hline & 10 & 271 & 151 & 44 & 79 & 71 \\
\hline \multirow{3}{*}{$\begin{array}{l}\text { Mid-terraced house/apartment } \\
\text { archetypes }\end{array}$} & 11 & 271 & 151 & 44 & 79 & 71 \\
\hline & 12 & 258 & 144 & 44 & 81 & 69 \\
\hline & 13 & 500 & 191 & 62 & 107 & 78 \\
\hline
\end{tabular}

House standard scenarios, respectively compared to the Base Case scenario. Detached dwellings had the highest primary energy use for all options and exhibited the greatest absolute and percentage reductions compared to other house types. Emissions findings were similar to those for energy.

With regard to the policy implications of this work, it would be recalled that the energy efficient upgrade of detached dwellings results in the greatest energy and emissions savings of all archetypes studied. These dwellings therefore deserve further study to establish whether they offer best value-for-money to the taxpayer. The current policy focus on minimising operational energy and emissions is justified given its dominance for all the options studied. However, adequate attention should also be given to reducing the proportion of embodied energy. This is particularly crucial since the proportion of embodied energy will increase significantly in the future as the energy performance of both existing and new dwellings (including operational phase zero/energy-plus dwellings) increases through the tightening of associated building regulations.

\section{Acknowledgement}

The authors gratefully acknowledge the support of the CODEMA and Sustainable Energy Authority Ireland for providing data for this work. The research was funded by the Dublin Institute of Technology's ABBEST programme.

\section{References}

[1] Pulselli M, Simoncini E, Pulselli F, Bastianoni S. Emergy analysis of building manufacturing, maintenance and use: em-building indices to evaluate housing sustainability. Energy Build 2007;39:620-8.

[2] Lechtenböhmer S, Schüring A. The potential for large-scale savings from insulating residential buildings in the EU. Springer Science + Business Media; 2010. p. $1-14$.

[3] Shorrock LD, Dunster JE. The physically-based model BREHOMES and its use in deriving scenarios for the energy use and carbon dioxide emissions of the UK housing stock. Energy Policy 1997;25(12):1027-37.

[4] Johnston D, Lowe R, Bell M. An exploration of the technical feasibility of achieving $\mathrm{CO}_{2}$ emission reductions in excess of $60 \%$ within the UK housing stock by the year 2050. Energy Policy 2005;33:1643-59.

[5] Boardman B, Darby S, Killip G, Hinnells M, Jardine CN, Palmer J, et al. The 40\% house report environmental change institute. Oxford: University of Oxford; 2005.

[6] Balarasa CA, Gaglia AG, Georgopoulou E, Mirasgedis S, Sarafidis Y, Lalas DP. European residential buildings and empirical assessment of the Hellenic building stock, energy consumption, emissions and potential energy savings. Build Environ 2007;42:1298-314.

[7] Clinch J, Healy J. Cost-benefit analysis of domestic energy efficiency. Energy Policy 2001;29:113-24.
[8] Clinch J, Healy J, King C. Modelling improvements in domestic energy efficiency. Environ Modell Softw 2001;16:87-106.

[9] Erlandsson M, Levin P. Environmental assessment of rebuilding and possible performance improvements effect on a national scale. Build Environ 2004;39: 1453-65.

[10] DoEHLG (Department of Environment Heritage and Local Government) Statutory instrument building regulations (Part L amendment) regulations; 2010.

[11] SEAI (Sustainable Energy Authority Ireland). See the Light 2009 Part L, building energy ratings and the passive house standard; 2009.

[12] SEAI (Sustainable Energy Authority Ireland). Low energy, low carbon and passive houses: a consumer guide; 2010.

[13] SEAI (Sustainable Energy Authority Ireland) and Passive House Academy Ireland. Passive house planning package - the essential passive house design tool; 2010.

[14] EC (European Commission). EPBD directive 2010/31/EU on the energy performance of buildings (recast). Article 9; 2010.

15] Famuyibo AA, Duffy A, Strachan P. Developing archetypes for domestic dwellings - an Irish case study. Energy Build 2012;50:150-7.

[16] International Standard Organisation. Environmental management - life cycle assessment - principles and framework. Geneva, Switzerland: International Standards Organisation; 2006.

[17] International Standard Organisation. Environmental management - life cycle assessment - requirements and guidelines. Geneva, Switzerland: International Standards Organisation; 2006.

[18] DCENR. (Department of Communications Energy and Natural Resources). Maximising Ireland's energy efficiency - the National Energy Efficiency Action Plan (NEEAP) 2009 - 2020; 2009.

[19] Blengini GA. Life cycle of buildings, demolition and recycling potential: a case study in Turin, Italy. Build Environ 2009;44:319-30.

[20] Sartori I, Hestnes A. Energy use in the life cycle of conventional and low energy buildings: a review article. Energy Build 2007;39:249-57.

[21] Nemry F, Uihlein A, Colodel CM, Wetzel C, Braune A, Wittstock B, et al. Options to reduce environmental impacts of residential buildings in the European Union - potential and costs. Energy Build 2010;42:976-84.

[22] Adalberth K. Energy use during the life cycle of single-unit dwellings: a method. Build Environ 1997;32(4):321-9.

[23] Scheuer C, Keoleian GA, Reppe P. Life cycle energy and environmental performance of a new university building: modelling challenges and design implications. Energy Build 2003;35:1049-64.

[24] Watson D, Williams J. Irish national survey of housing quality (INSHQ 2001 2002). The Economic and Social Research Institute (ESRI); 2003. Watson and Williams.

[25] EST (Energy Saving Trust) Domestic low and zero carbon technologies (2010 edition).

26] ENERGY STAR. Save money and more with energy STAR. Qualified solar wate heaters. Available on http://www.energystar.gov/index.cfm?c=solar wheat. pr_savings_benefits.

[27] EST (Energy Saving Trust). Using whole life cycle costing as a basis for investments in energy efficiency - guidance (2005 edition).

[28] Sustainable Energy Authority Ireland and CODEMA (County of Dublin Energy Management Agency). Energy performance survey of Irish housing (EPSIH) database and final report; 2005.

[29] Clarke JA, Ghauri S, Johnstone CM, Kim JM, Tuohy PG. The EDEM methodology for housing upgrades analysis, carbon and energy labelling and national policy development. In: The proceedings of the IBPSA eSim conference, Quebec City Canada 2008. p. 135-42.

[30] LBP \& PE, GaBi 4.4. Software system and databases for life cycle engineering. Department of Life Cycle Engineering, Chair of Building Physics, Stuttgart University \& PE International; 2007. Gmbh. 
[31] Acquaye AA. A stochastic hybrid embodied energy and $\mathrm{CO}_{2}$-eq intensity analysis of building and construction processes in Ireland. Dublin Ireland: Dublin Institute of Technology; 2010. PhD thesis.

[32] Suh S, Huppes G. Missing inventory estimation tool using extended inputoutput analysis. Int J Life Cycle Ass 2002;7:134-40.

[33] Spon. Spon's Irish construction price book. 3rd ed. United Kingdom: TJ International Limited; 2008.
[34] Spon. Spon's mechanical \& electrical services price book. 42nd ed. United Kingdom: Spon Press; 2011.

[35] Brophy V, Clinch J, Convery FJ, Healy J, King C, Lewis JO. Homes for the 21st century: the costs and benefits of comfortable housing in Ireland. Dublin: Energy Action; 1999.

[36] Famuyibo AA. Reducing life cycle impacts of the existing Irish housing stock. Dublin Ireland: Dublin Institute of Technology; November, 2010. PhD thesis. 